\title{
SPECIFIC ASPECTS OF STRATEGIC ENTREPRENEURSHIP IN FAMILY COMPANIES AND NON-FAMILY COMPANIES
}

\author{
Siniša M. Arsić, MSc, \\ Faculty of organizational sciences, 11000 Belgrade, \\ arsa.arsa@hotmail.com, +381646503293
}

\section{Original Scientific Paper doi:10.5937/jouproman5-12891}

\begin{abstract}
The paper presents a theoretical analysis of the strategic innovation attributes that are represented in family companies, and the paper cross examinates a significant number of references dealing with this topic. In the reviewed literature, one aspect is usually imposed as a basis for comparison and evaluation of innovation in family companies, and it is "strategic entrepreneurship" (functional link of strategy and idea generation from an individual or a team of people). The abovementioned aspect is not analyzed in detail in the case of intrapreneurship in non-family companies. The aim of this paper is in realization of high-quality supplements or conclusions from the literature dealing with strategic entrepreneurship. The originality of this work lies in the analysis and comparison of family and non-family companies, by amending the variables that define strategic enterpreneurship. Thus, it allows the applicability of the same variables in the case of analysing family and non-family companies, and also identifies variables unique to a family company.
\end{abstract}

Keywords: strategy, entrepreneurship, innovation, innovation project

\section{INTRODUCTION}

Previous studies of strategic entrepreneurship are mainly comprised of family companies, but in the case of nonfamily companies, the term is mentioned as "intrapreneurship" or individualism within large corporations.

The emphasis in the observation of individualistic entrepreneurship in nonfamily companies is the freedom of the individual to implement the ideas and initiatives, than of the opposition group's attitudes and beliefs (for the purpose of realization of ideas) (Morris et al, 1993).

Meanwhile, studies of family companies viewed entrepreneurship through strategic attributes (aspects) such as innovation, proactiveness and risk taking.

Although a number of studies in reputable journals deal with comparative analysis of the peculiarities and specific aspects of family-owned companies compared to non-family companies, very few studies have treated variables that are related to specificities of strategic entrepreneurship in family companies, and which variables can be used in a complementary analysis of family and nonfamily companies.

Discussion of the results of research are trying to "reconcile" different views of foreign authors on this subject, but also to provide a vision of the future research of the author.

\section{SPECIFIC ASPECTS OF STRATEGIC ENTREPRENEURSHIP}

For easier following of the specificity and uniqueness of the variables that are related to family / non-family environment, further theoretical research is divided into aspects of family and non-family aspects of the company.

\section{Aspects dealing with family businesses}

Often the owners of family companies engage external advisors to counsel with the goal of increasing the level of creativity in the company. The result of engagement of external collaborators can lead to resistance of family members in the company, leading to a lower level of innovation (Lorenzo Cacho \& Nunez, 2015). 
Studies have generally found that there is causality between family ties in the company with the outcomes of innovation (Classen et al, 2014).

In a survey conducted by Matzler and associates (2015), there is an established causality between innovation performance, in a way that innovation in family businesses are more effective than in non family businesses. The problem is that the decision to implement an innovation brings weight (unwillingness to risk and hesitancy to change).

The research of and Cassia De Massis (2012) on a sample of ten Italian SMEs (family and non-family), identified nine variables specific only to family companies, which directly affect the strategic innovation and development of new products within the company's business: - Long-term orientation in strategic planning;

- Conservative in strategic planning and minimization of risk; - Oversized number of employees, causing in some cases increased availability to generate ideas and develop products / services;

- Advocating innovation leaders (usually the owner) provides high motivation, cohesiveness of family members within the company;

- The low level of openness to outside ideas and external capital for innovation; - Low readiness for innovation, creativity and change in general. This entails difficulties in the adoption of system solutions for the generation of new ideas; - High level of communication between team members as part of the innovation activity, and therefore the higher the frequency of conflicts; - Focused control and efficiency in spending,

- Visibility and reputation of the family in the wider community.

The main causes of the lack of efficiency in the implementation of an innovation, are the result of a lower share of human resources in the current generation of innovative features, and a lower proportion of employees who are eligible for the implementation of innovation (Liach \& Nordqvist, 2010).

However, within the same survey it is stated that family companies have a greater possibility of "networking", ie cooperation with other companies (human capital for innovation). Cooperation according to the same research takes place in most areas of production, procurement and sales. In addition to human capital, which is more pronounced in family companies, studies show that family culture in some cases is transferred into organizational culture, and thus stimulates innovation in the company (capacity to generate ideas and develop new products / services / processes) and has a direct impact on business performance (Craig et al, 2014).

Also, there is a correlation between the share of the family wealth invested in the family business and the intensity of innovation. The conclusion is that the greater the share of the family wealth is invested in the capital of the company, there is less willingness to take risks and there is a lower level of investment in innovation (Sciascia et al, 2015).

\section{Aspects dealing with non-family companies}

Complementarity of strategic entrepreneurship variables related to family and non-family companies is essential due to the fact that $80 \%$ of innovation in developed countries originates from nonfamily, large companies (Hitt et al, 2001). If we take into account that individual creativity is prerequisite for generating ideas, ie the divergent processes within the organization, then it must be concluded that the precondition for the successful execution of innovation (commercialization of ideas) is exactly the existence of convergent processes that deal with the sterile juxtapositions using standard tools, techniques and models of doing business. 
Only through formal established and generally accepted elements can be implemented an innovation, reaching the commercialization phase (Palmer\&Kaplan, 2015).

It can be concluded that "entrepreneurship" is possible and realistically sustainable only through the formal support of management structures, but also with the strive of a team effort, which provides real effects of innovation.

In one study on proactivity, innovation and risk taking, on a sample of Finnish SMEs (family and non-family), the main conclusion is that there is a more pronounced positive correlation between the ability to take risks and results of innovation activities, with the non-family companies in relation to the family companies (Craig et al, 2014b).

Rod (2016) conducted a very comprehensive study that cross examined albeit 78 studies dealing with the innovation of family companies. It can be concluded that the dominant themes in these studies are:

- Output (impact) of innovation activity;

- Innovation activity and

- Impacts on the implementation phase of innovation.

Positive impact on the output of innovative activities are the long-term orientation and motivation, preservation of ownership and control, as well as the dynamics of the family company (cooperation between older and younger generations).

Positive impact on innovation activity also is the willingness of owners to parsimony (or keeping the acquired wealth for future generations), and also control of the lower layers of management, collective orientation, family connections (closeness) and solid leadership of the owners.
As the largest negative impacts among the analyzed sources stand out nepotism, conflict of interest, conservatism and risk avoidance, closedness to external partners (Rod, 2016).

Regarding the systemic approach in facilitating strategic entrepreneurship, one of the ways that non-family companies (medium and large) have the resources and capacity, is by establishing innovation centers and places where the development of existing products / services / processes will be a cyclic process, not just an event.

On the other hand, according to Afuah (2009), strategic thinking should be applied to identify opportunities for innovation, citing several "new" sources of ideas for innovation:

- creation of new resources or the adaptation of existing resources to a new purpose,

- better anticipation of competitors' action(taking leadership roles) - exploitation of opportunities from the macro environment, within the same industry or even other markets - fuller utilization of key competencies of human resources within the different departments of the company (intercompatibility).

In the study, Wolf et al (2011) on a sample of SMEs in Switzerland, there were identified four profiles of innovation and entrepreneurship: holistic, network-based, "do it yourself" and resistance to innovation. In the holistic profile of SMEs, innovation is at the heart of organizational culture and represent the core of the strategic activities of the company. Network-based entrepreneurship relies on the intersection of various external sources of creativity (universities, business associates, consultants). In "do it yourself" profile, personal competences ("intrapreneurship") are the key to generating ideas and represent a major capacity for innovation. 
The last profile that was studied, refers to resistance to innovation, this model is recorded in a single observed family business and there is present resistance to any change and innovation is not being invested in at all (Wolf et al, 2011).

One of these profiles of innovationnetwork based profile is analyzed in another study, representing a possible solution to overcome the gap in the continuity of innovation cycles. The conclusion is that the cooperation and mutual work on innovation with other SMEs, is a bigger goal to acquire more wealth (the product of cooperation in the form of ideas, innovation, business performance) than to produce failure and loss as a result of sharing information with potential competitors (Ketchen et al, 2007).

Matsuno et al (2014) in their study treated tendency towards entrepreneurship in large Japanese corporations (non-family companies). The main conclusions are as follows:

- there is a direct positive correlation between the propensity for entrepreneurship and integration of marketing and $\mathrm{R} \& \mathrm{D}$ functions and

- there is a direct positive correlation between the propensity for entrepreneurship and business development, and favorable financial effects.

\section{Discussion of research results}

Based on the theoretical review of a significant number of references that have analyzed the family and non-family companies, one of the conclusions to be reached is that networking, responsiveness to customer requirements, proactiveness, risk-taking and optimization of financial resources, and also innovation are factors that are common to family and non-family companies.

If each of these factors is present in an increased extent, it is a radical innovation, and such companies are among aggressive innovators (Eggers et al, 2016).

There are different views from those presented in the main part of this paper. For example, Beck (2009) states that employees of family businesses are often excluded from the process of generating ideas, decision making processes, or choosing between a multitude of opportunities for innovation. As a means to overcome this problem, teamwork and effective communication between management levels are introduced, which can be and are a characteristic of both non-family and family-owned companies.

The study which dealt with the objectives of profitability, control and results of research and development activities in the context of family and nonfamily companies, examined on a sample of Spanish companies, presents the following conclusions:

- in family companies, non-economic objectives are predominant, such as control objectives,

- In non-family companies the power of bargain is "integrated" into the objectives of achieving profit, while in family companies it is a mechanism of control and power over individuals, and

- in family companies in terms of the inability to achieve the objectives of profitmaking, decision is often to increase strategic investments in research and development (innovation), which will bring greater long-term profit, while non-family companies decide to avoid the risk (Kotlar et al, 2014).

Tidd i Bessant (2014) claim that it is common for companies (whether small, medium or large, regardless of the ownership structure) for innovation process to be successful, it is necessary to have clear strategic leadership, and a business climate that allows creativity and birth of ideas, proactive networking internally and externally. 
The strategic objective and vision should be to enable the process of organizational learning starting from the phase of entrepreneurial ideas to the moment of creation of new, additional value, which was not previously possible.

\section{CONCLUSION}

This paper investigated the specifics of family-owned companies compared to those that are not, in terms of strategic entrepreneurship. A gap was identified in the existing literature, which is due to the fact that there is not a single unified analysis of the variables that define strategic enterpreneurship, depending on the family / nonfamily business environment, in which entrepreneurship is implemented. Also, very little work has examined variables that are compatible in comparing the performance of family and non-family companies.

The presents presents a good introduction to the further quantitative research that would examine the parameter defined variables that are specific to the family / non-family companies. In this way it may be possible to create a model for understanding the performance of strategic entrepreneurship in family and non-family companies.

\section{LITERATURE}

[1] Affuah, A. (2009): Strategic Innovation. New Game Strategies for Competitive Advantage, Routledge, New York

[2] Beck, L., Janssens, W., Lommelen, T., Sluismans, R. (2009):Research on innovation capacity antecedents: distinguishing between family and non-family businesses, KIZOK Research Centre, Belgium

[3] Cassia, L., De Massis, A., Pizzurno, E. (2012):Strategic innovation and newproduct development in family firms. An empirically grounded theoretical framework, International Journal of Entrepreneurial Behaviour and Research, 18(2)

[4] Classen, N., Caree, M., Van Gils, A., Peters, B. (2014): Innovation in family and non-family
SMEs: an exploratory analysis, Small Business Economics, 42

[5] Craig, J.B., Pohjola, M., Kraus, S., Jensen, S.H. (2014a):Exploring Relationships among Proactiveness, Risk-Taking and Innovation Output in Family and Non-Family Firms, Creativity and Innovation Management, 23(2)

[6] Craig, J.B. Dibrell, C., Garett, R., (2014b):Examining relationships among family influence, family culture,flexible planning systems, innovativeness and firm performance, Journal of Family Business Strategy, 5

[7] Eggers, F., Cheng-Feng, C., Man-Ling, C. (2016):Radical Innovativeness in Family and NonfamilyFirms: A Configuration Approach, Research Gate

[8] Hitt, M. A., Ireland, R.D., Camp, M.S., Sexton, D.L. (2001):Strategic Entrepreneurship: Integrating Entrepreneurial and Strategic Management Perspectives, Strategic Management Journal, 22(special edition)

[9] Ketchen, D.J., Ireland, R.D., Snow, C.C. (2007): Strategic entrepreneurship, collaborative innovation, and wealth creation, Strategic Entrepreneurship Journal, 1

[10] Kotlar, J., Fang, H., De Massis, A., Frattini, F. (2014): Profitability Goals, Control Goals, and the R\&D InvestmentDecisions of Family and Nonfamily Firms, Product Development\& Management Association, 31(6)

[11]Liach, J., Nordquist, M., (2010):Innovation in Family and Non-FamilyBusinesses: A Resource Perspective, International Journal of Entrepreneurial Venturing, 2(3)

[12]Lorenzo, D., Nunez Cacho, P. (2015): Some obstacles to innovation in family firms, Ifera 2015 Annual Conference - Session PP2 Innovation and Entrepreneurship, Hamburg, Germany

[13]Matsuno, K., Zhu, Z., Rice, M.P. (2014):Innovation Process and Outcomes for Large Japanese Firms:Roles of Entrepreneurial Proclivity and Customer Equity, 31(5)

[14] Matzler, K., Veider, V., Hautz, J., Stadler, C. (2015):The Impact of Family Ownership, Management, andGovernance on Innovation, Journal of Product Innovation Management, $32(3)$

[15] Morris, M.H., Avila R.A., Allen, J. (1993):Individualism and the Modern Corporation: Implications for lnnovation and 
(JPMNT) Journal of Process Management - New Technologies, International

Vol. 5, No 1, 2017.

Entrepreneurship, Journal of Management, 19(3)

[16]Palmer, D., Kaplan, S. (2015): A Framework for Strategic Innovation. Blending strategy and creative exploration to discover future business oportunities, Innovation Point, 2015

[17]Rod, I. (2016):Disentangling the familyfirm's innovation process: A systematicreview, Journal of Family Business Strategy, 7

[18] Sciascia, S., Nordquist, M., Mazzola, P., De Massis, A. (2015), Family Ownership and R\&D Intensity in Small- and Medium-Sized Firms, Journal of Product Innovation Management, 32(3)

[19] Tidd, J., Bessant, J. (2015): Innovation and Entrepreneurship, Research Gate

[20] Wolf, P., Kaudela-Baum, S., Meissner, J.O. (2011):Exploring innovating culturesin small and medium-sizedenterprises: Findings from Central Switzerland, International Small Business Journal, 30(3) 